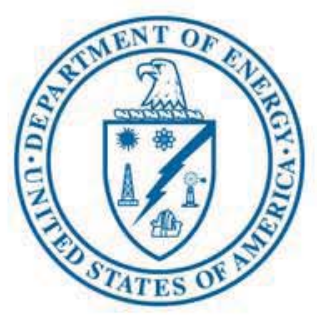

U.S. Department of Energy

Idaho Operations Office

\title{
Mission Need Statement for the Idaho National Laboratory Remote-Handled Low-Level Waste Disposal Project
}

A Non-Major System Acquisition Project

June 2009 


\section{Mission Need Statement for the Idaho National Laboratory Remote-Handled Low-Level Waste Disposal Project}

A Non-Major System Acquisition Project

June 2009 

Mission Need Statement for the Idaho National Laboratory Remote-Handled Low-Level Waste Disposal Project

DOE/-ID-11364

June 2009

Concurrence:

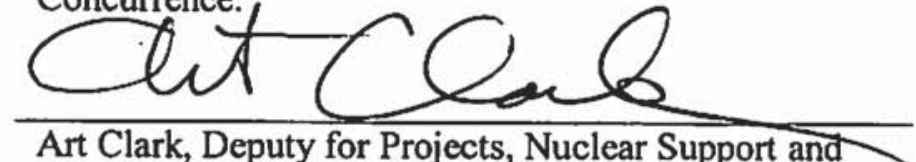

Art Clark, Deputy for Projects, Nuclear Support and Production

Battelle Energy Alliance, LL

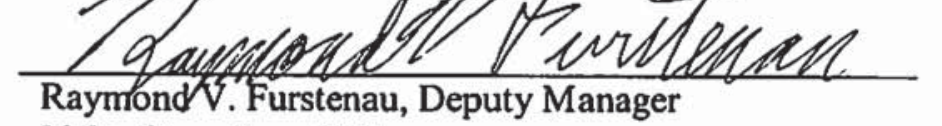

Idaho Operations Office

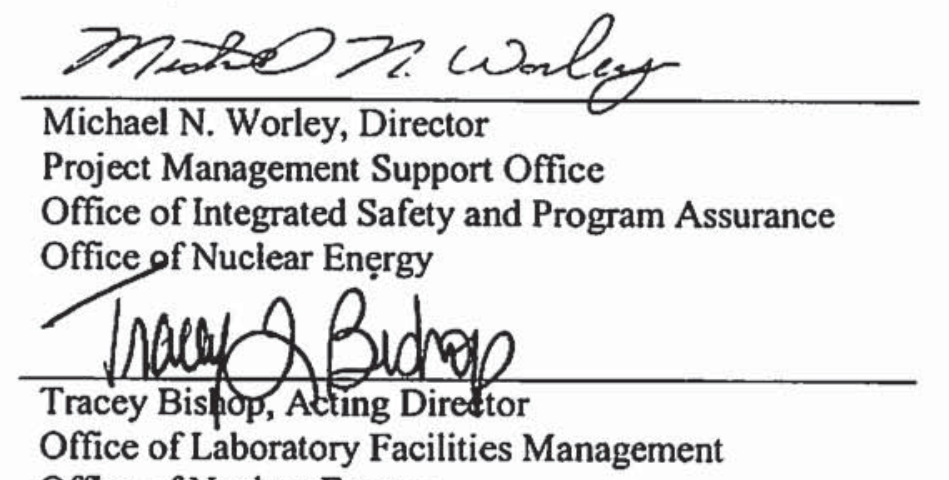

Office of Nuclear Energy

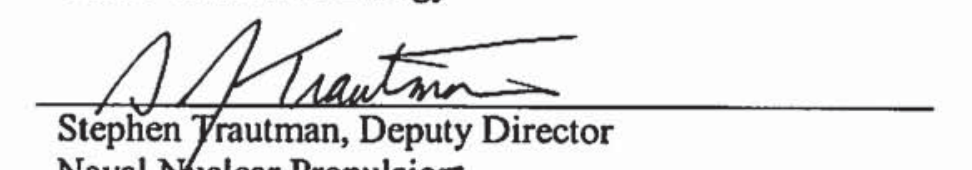

Naval Nuclear Propulsiger

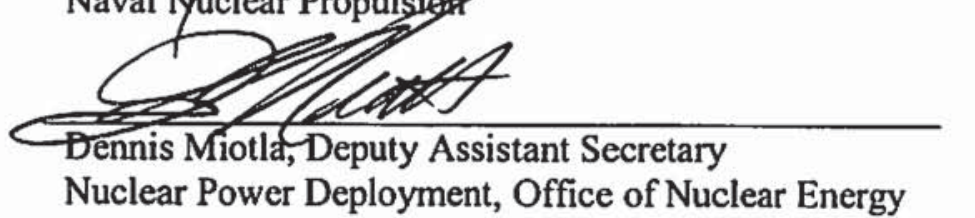
Interim Manager, Idaho Operations Office

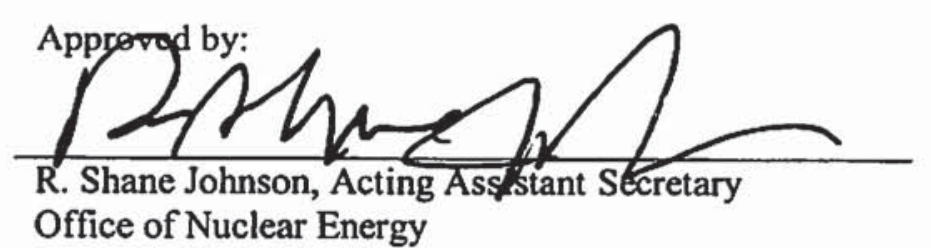

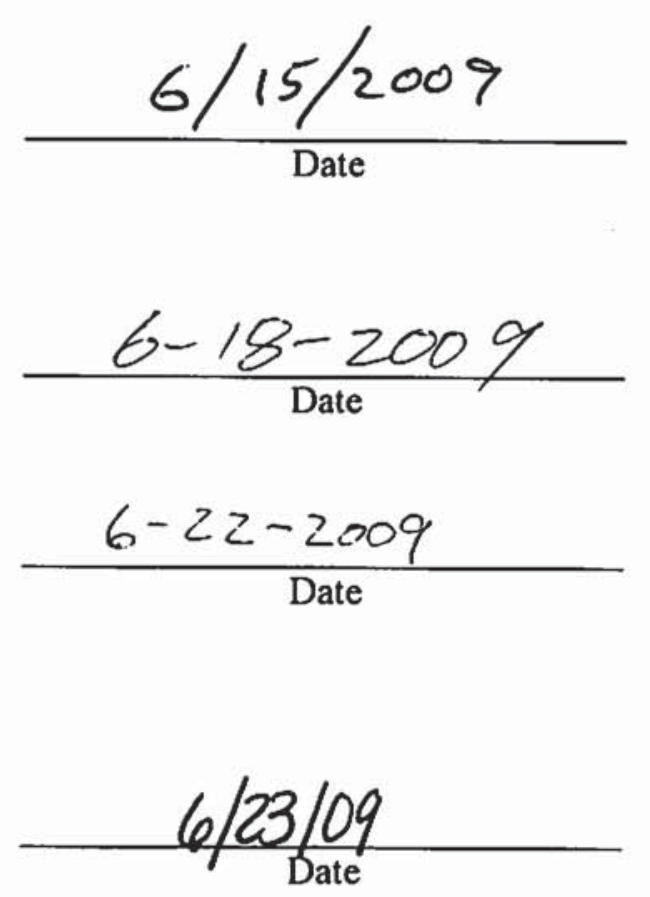
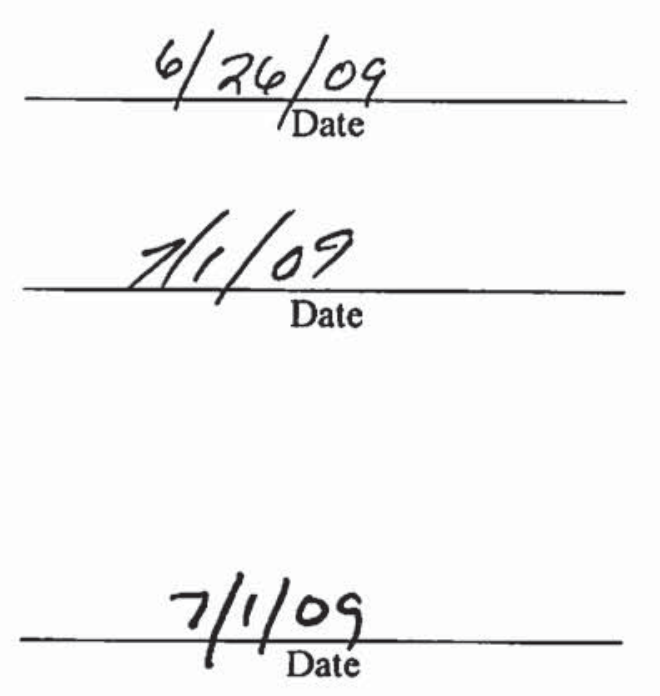
ENDORSEMENTS/RECOMMENDATIONS

Project: Remote Handled-Low Level Waste

Type of Review: Pre-Non-Major Systems Advisory Board Review Decision Type: $\underline{\text { Critical Decision-0, Approve Mission Need }}$

The undersigned "Do Recommend" (Yes) or "Do Not Recommend" (No) approval of CD -0 "Approve Mission Need," for the Remote Handled-Low Level Waste Project as noted below. Rom eld 3 ares $6 / 29 / 09$ Don Barnes, Office of Laboratory Facilities Management (NE-32)

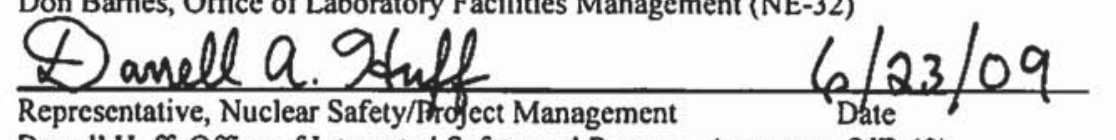

Darrell Huff, Office of Integrated Safety and Program Assurance (NE-43)

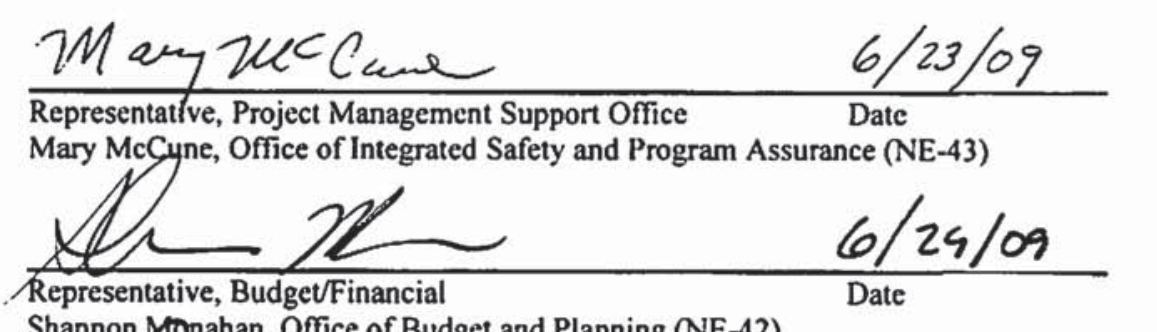

Shannon prgnahan, Office of Budget and Planning (NE-42)



Steve Reeves, Office of Integrated Safety and Program Assurance (NE-43)

$$
\frac{\mathrm{R} \text { u ld }}{\text { Representative, Project Management }} \text { 6/23/09 }
$$

Rich Rester, Office of Light Water Reactor Deployment (NE-31)






\section{EXECUTIVE SUMMARY}

The Idaho National Laboratory proposes to establish replacement remote-handled low-level waste disposal capability to meet Nuclear Energy and Naval Reactors mission-critical, remote-handled low-level waste disposal needs beyond planned cessation of existing disposal capability at the end of Fiscal Year 2015. Remote-handled low-level waste is generated from nuclear programs conducted at the Idaho National Laboratory, including spent nuclear fuel handling and operations at the Naval Reactors Facility and operations at the Advanced Test Reactor. Remote-handled low-level waste also will be generated by new programs and from segregation and treatment (as necessary) of remote-handled scrap and waste currently stored in the Radioactive Scrap and Waste Facility at the Materials and Fuels Complex. Replacement disposal capability must be in place by Fiscal Year 2016 to support uninterrupted Idaho operations.

This mission need statement provides the basis for the laboratory's recommendation to the Department of Energy to proceed with establishing the replacement remote-handled low-level waste disposal capability, project assumptions and constraints, and preliminary cost and schedule information for developing the proposed capability. Without continued remote-handled low-level waste disposal capability, Department of Energy missions at the Idaho National Laboratory would be jeopardized, including operations at the Naval Reactors Facility that are critical to effective execution of the Naval Nuclear Propulsion Program and national security. Remote-handled low-level waste disposal capability is also critical to the Department of Energy's ability to meet obligations with the State of Idaho. 


\section{CONTENTS}

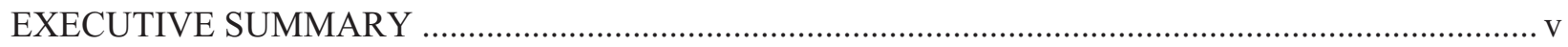

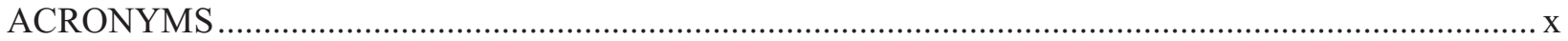

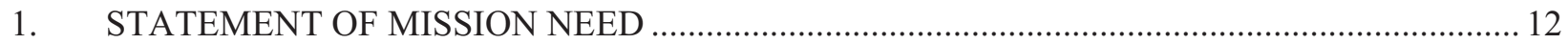

1.1 Contact and Remote-Handled Low-Level Waste Disposal ............................................ 13

1.2 Idaho National Laboratory Remote-Handled Low-Level Waste Disposal Project ............ 13

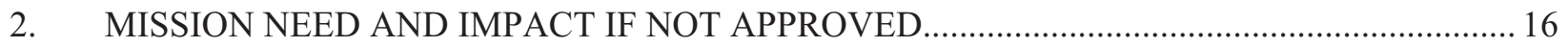

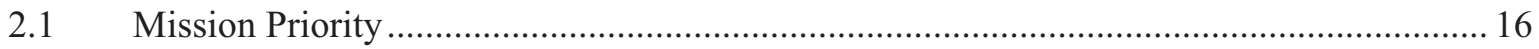

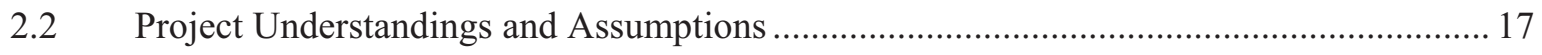

2.3 Project Support of Department of Energy Goals ......................................................... 18

2.4 Impact If Proposed Mission is Not Approved …............................................................ 19

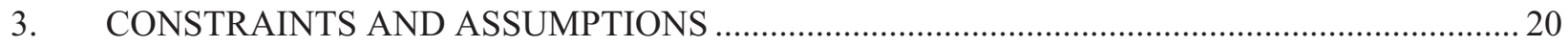

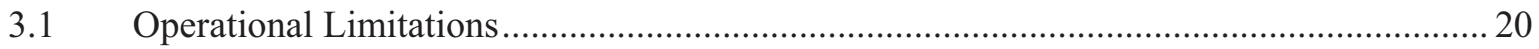

3.2 Environmental, Geographic, and Organizational Limitations .......................................... 21

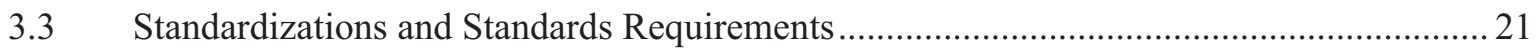

3.4 Environmental, Safety, and Health Requirements......................................................... 21

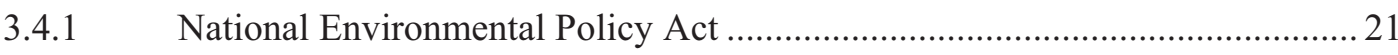

3.4.2 Disposal Facility Waste Acceptance Criteria .................................................22

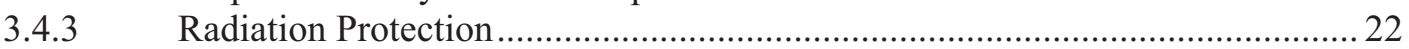

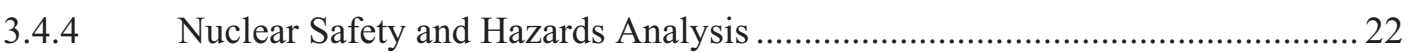

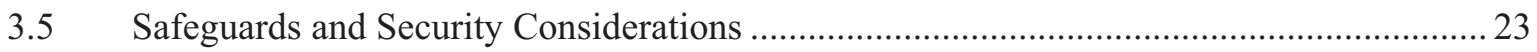

3.6 Interfaces with Existing and Planned Acquisitions .................................................. 24

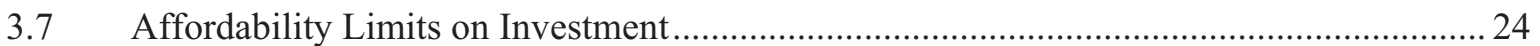

3.8 Goals for Limitations on Recurring or Operating Costs................................................. 24

3.9 Legal and Regulatory Constraints and Requirements ................................................... 24

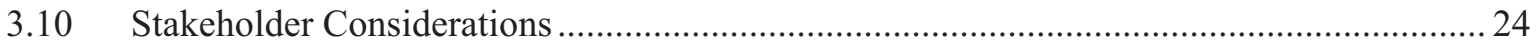

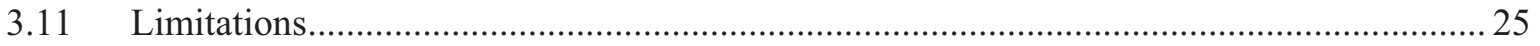

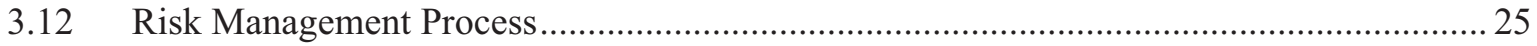




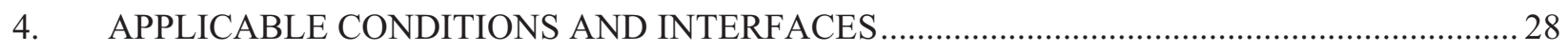



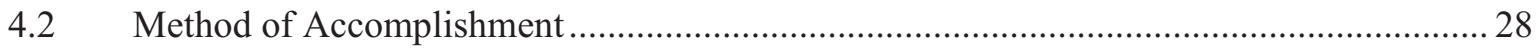

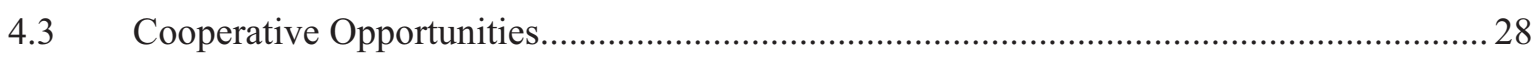

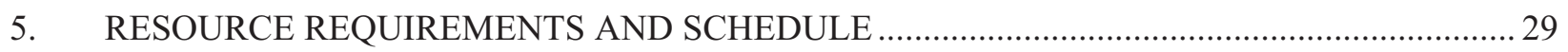

5.1 Timeline

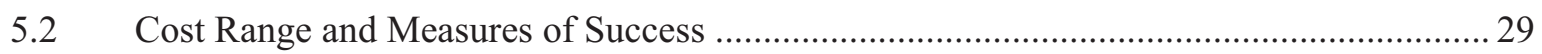

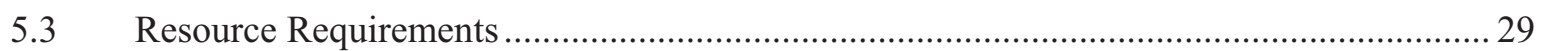

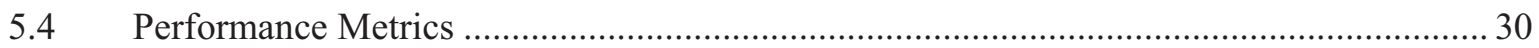

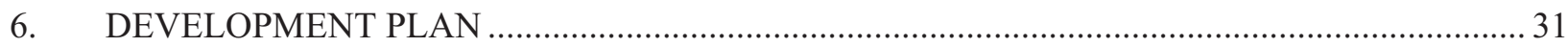

6.1 Planning and Coordination with Current Programs Efforts ............................................ 31

6.2 Activities and Schedule to Meet Milestones and Critical Decisions ................................ 31

6.3 Concept Development Approach and Expected Outcome …........................................... 31

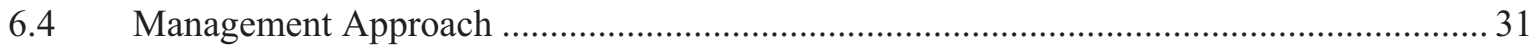

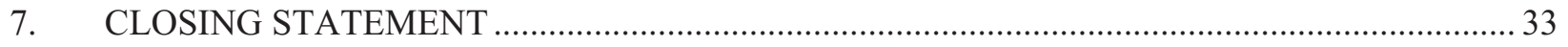

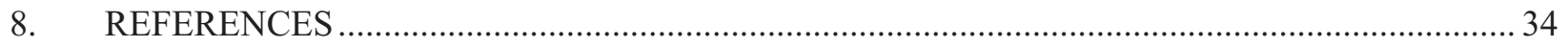

Appendix A, Contact and Remote-Handled Low-Level Waste Disposal ............................................... 37

\section{FIGURES}

1. Idaho National Laboratory remote-handled low-level waste generation.

\section{TABLES}

1. Potential risk categories..... 


\section{ACRONYMS}

ATR Advanced Test Reactor

CD critical decision

CERCLA Comprehensive Environmental Response, Compensation, and Liability Act

DOE U.S. Department of Energy

DOE-ID U.S. Department of Energy, Idaho Operations Office

DOT U.S. Department of Transportation

EM Office of Environmental Management

FY fiscal year

INL Idaho National Laboratory

LLW low-level waste

MFC Materials and Fuels Complex

NE Office of Nuclear Energy

NEPA National Environmental Policy Act

NNSA National Nuclear Security Administration

NR Office of Naval Reactors

NTS Nevada Test Site

ROD record of decision

RWMC Radioactive Waste Management Complex

SDA Subsurface Disposal Area

WAC waste acceptance criteria 


\title{
Mission Need Statement for the Idaho National Laboratory Remote-Handled Low-Level Waste Disposal Project
}

\author{
A Non-Major Systems Acquisition Project \\ 1. STATEMENT OF MISSION NEED
}

The Idaho National Laboratory (INL), an 890-square-mile section of desert in southeast Idaho, was established in 1949 as the National Reactor Testing Station. Initially, the missions at INL were development of civilian and defense nuclear reactor technologies and management of spent nuclear fuel. Today, INL is a multipurpose national laboratory delivering specialized science and engineering solutions for the U.S. Department of Energy (DOE). Sponsorship of INL was formally transferred to the DOE Office of Nuclear Energy (NE) by Secretary Spencer Abraham in July 2002. The move to NE, and designation along with Argonne National Laboratory as the DOE lead nuclear energy laboratories for reactor technology, supports the nation's expanding nuclear energy initiatives, placing INL at the center of work to develop advanced Generation IV nuclear energy systems; nuclear energy/hydrogen coproduction technology; advanced nuclear energy fuel cycle technologies; and providing national security answers to national infrastructure needs. In addition, INL hosts the National Nuclear Security Agency's (NNSA's) Naval Reactors Facility (NRF). NRF supports the U.S. Navy's nuclear-powered fleet through research and development of materials and equipment as assigned by the Office of the Deputy Administrator for Naval Reactors (NR).

The DOE Idaho Operations Office (DOE-ID) also is executing the Office of Environmental Management (EM) cleanup mission concurrently with the critical scientific and nuclear energy-related research and development mission of NE. As part of ongoing cleanup activities at INL, closure of the Radioactive Waste Management Complex (RWMC) is proceeding under the Comprehensive Environmental Response, Compensation, and Liability Act (CERCLA) (42 USC 9601 et seq. 1980). INL-generated radioactive waste has been disposed of at RWMC since 1952. Currently, the Subsurface Disposal Area (SDA) at RWMC accepts the bulk of INL's contact and remote-handled low-level waste (LLW) for disposal. Disposal of contact-handled LLW and open pit disposal of Advanced Test Reactor (ATR) remote-handled LLW ion-exchange resins in the SDA is planned to cease by September 30, 2008. Disposal of NRF-generated remote-handled LLW in concrete disposal vaults at RWMC will continue until the facility is full or until it must be closed in preparation for final remediation of the SDA (approximately at the end of fiscal year [FY] 2015). Implementation of the RWMC Record of Decision (ROD) is not likely to impact remote-handled LLW disposal prior to September 30, 2012; however, it may impact remote-handled LLW disposal prior to the end of FY 2015. The EM contractor will implement the ROD in a manner that supports operation of the remote-handled LLW disposal vaults through the end of FY 2015, if possible, subject to the provisions of the ROD.

The continuing nuclear mission of INL, associated ongoing and planned operations, and Naval spent fuel activities at NRF require continued capability to appropriately dispose of remote-handled LLW. Providing continued disposal capability for remote-handled LLW supports NE's mission "to lead the DOE investment in the development and exploration of advanced nuclear science and technology." Without established, viable remote-handled LLW disposal capability, ongoing and future nuclear energy programs at INL would be adversely impacted as remote-handled LLW disposal options would need to be considered on a program-by-program basis, resulting in increased costs and schedule. The lack of 
remote-handled LLW disposal capability may also impede DOE's ability to initiate new programs at the INL.

Remote-handled LLW disposal capability is also critical to meeting NNSA's mission to "provide the United States Navy with safe, militarily effective nuclear propulsion plants and to ensure the safe and reliable operation of those plants." All spent nuclear fuel from the Navy's nuclear-powered fleet is sent to NRF for examination, processing, dry storage, and eventual shipment to a permanent geologic repository. A reliable disposal path for remote-handled LLW generated during spent nuclear fuel handling and packaging operations is essential to NRF's continued receipt and processing of Navy spent fuel and, therefore, to the Naval Nuclear Propulsion Program and to national security as well.

The mission need statement for the INL Remote-Handled LLW Disposal Project, created as a result of evaluating INL remote-handled LLW disposal options, is as follows:

"The INL will develop replacement remote-handled low-level waste disposal capability by the end of Fiscal Year 2015 to support cost-effective, efficient operations in support of INL's nuclear energy mission and the Naval Nuclear

Propulsion Program. Such disposal capability is required to enhance ongoing Departmental and National mission-based research, defense, and energy programs."

\subsection{Contact and Remote-Handled Low-Level Waste Disposal}

The DOE's Idaho programs have been coordinating efforts on waste management activities at INL. Plans and projects are in place to address DOE's legacy waste management issues and are being implemented by both EM and NE. Appendix A summarizes current INL contact and remote-handled LLW disposal activities. Plans and capabilities have been established for offsite disposal of all contact-handled LLW generated after September 30, 2008. The INL Remote-Handled LLW Disposal Project will provide for continued INL remote-handled LLW disposal capability beyond the end of FY 2015, when the existing disposal capacity is anticipated to be full or closed in preparation for final remediation activities. Figure 1 presents current and anticipated remote-handled LLW generation rates by generator.

\subsection{Idaho National Laboratory Remote-Handled Low-Level Waste Disposal Project}

Plans and capabilities are in place for offsite disposal of contact-handled LLW; therefore, the remainder of this mission need statement focuses on the need to establish uninterrupted remote-handled LLW disposal capability. INL proposes to establish replacement remote-handled LLW disposal capability for current disposal operations in the SDA. Remote-handled LLW is generated from nuclear programs conducted at INL, including spent nuclear fuel handling and operations at NRF and operations at ATR. Remote-handled LLW also will be generated by new programs and from segregation and treatment (as necessary) of remote-handled scrap and waste currently stored in the Radioactive Scrap and Waste Facility at the Materials and Fuels Complex. 


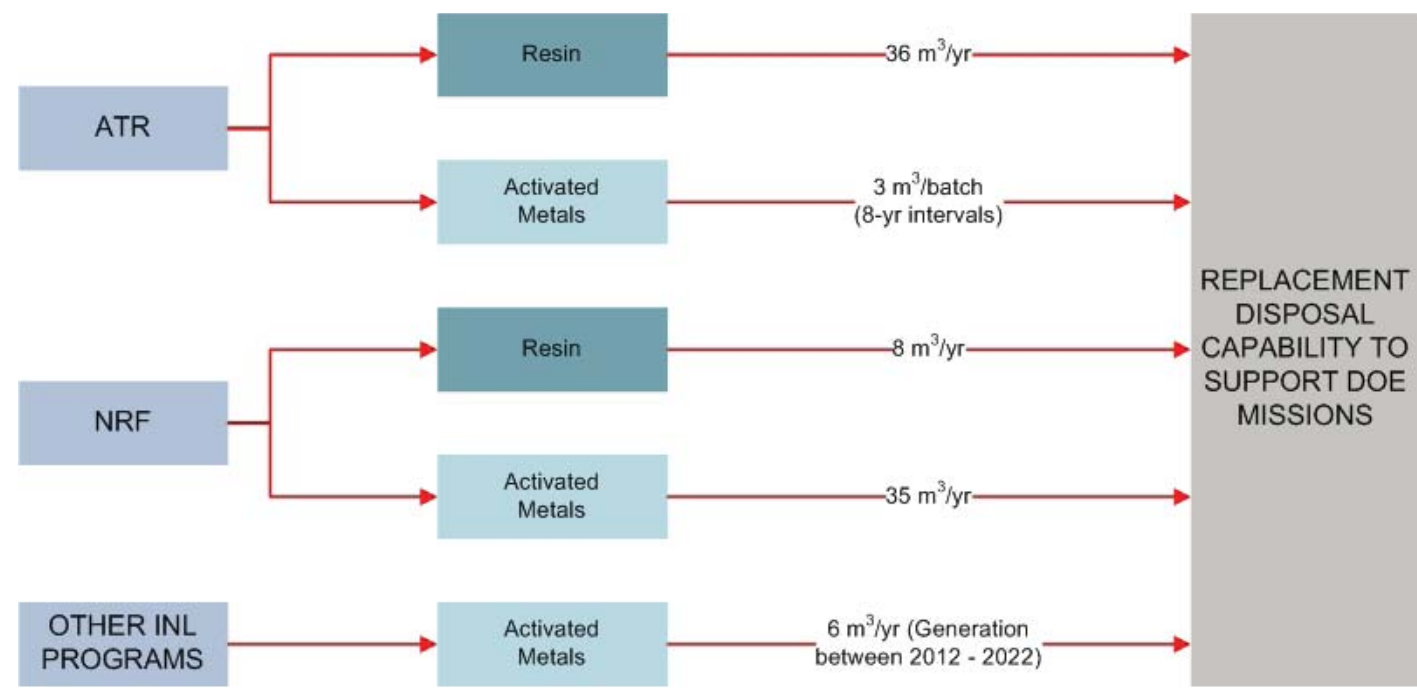

$\begin{array}{ccc}\begin{array}{c}\text { Generating } \\ \text { Facility }\end{array} & \begin{array}{c}\text { Remote-Handled } \\ \text { Waste Stream }\end{array} & \text { Waste } \\ \text { Generation Rate }\end{array}$

Figure 1. Idaho National Laboratory remote-handled low-level waste generation.

Implementation of the INL Remote-Handled LLW Disposal Project would yield the following benefits:

- $\quad$ Provide remote-handled LLW disposal capability, thereby minimizing potential impacts on existing INL and NRF operations

- $\quad$ Allow continued processing of Navy fuels at NRF in accordance with the Idaho Settlement Agreement (State of Idaho 1995; State of Idaho 2008)

- $\quad$ Provide remote-handled LLW management and disposal consistent with DOE O 435.1, "Radioactive Waste Management," which states:

"DOE radioactive waste shall be treated, stored, and in the case of low-level waste, disposed of at the site where the waste is generated, if practical"

- $\quad$ Provide a consistent, sitewide waste management system, reducing required coordination among multiple programs to identify and implement cost-effective waste management options.

The following alternatives have been initially identified as options for providing continued INL remote-handled LLW disposal capability. Each of these alternatives will be further evaluated as part of the National Environmental Policy Act (NEPA) and DOE O 413.3A processes:

- $\quad$ Alternative 1: Continued disposal at RWMC

- $\quad$ Alternative 2: Disposal at the Idaho CERCLA Disposal Facility

- $\quad$ Alternative 3: Interim storage

- $\quad$ Alternative 4: Storage for decay 
- $\quad$ Alternative 5: Development of onsite remote-handled LLW disposal facility

- $\quad$ Alternative 6: Offsite remote-handled LLW disposal (multiple offsite locations)

- $\quad$ Alternative 7: Privatization of remote-handled LLW disposal

- $\quad$ Alternative 8: No action. 


\title{
2. MISSION NEED AND IMPACT IF NOT APPROVED
}

As presented in Section 1, the following is the mission need statement for the INL Remote-Handled LLW Disposal Project:

"The INL will develop replacement remote-handled low-level waste disposal capability by the end of Fiscal Year 2015 to support cost-effective, efficient operations in support of INL's nuclear energy mission and the Naval Nuclear Propulsion Program. Such disposal capability is required to enhance ongoing Departmental and National mission-based research, defense, and energy programs."

This section addresses the INL Remote-Handled LLW Disposal Project mission priority as related to other Idaho and DOE missions, the project assumptions, project support of DOE missions, and impacts if the project is not approved.

\subsection{Mission Priority}

The need for continued remote-handled LLW disposal capability at INL was recognized by NE during development of the INL management and operations contract scope of work. The INL contract states the following:

\begin{abstract}
"The INL Contractor shall manage INL generated LLW and, if directed by DOE, $L L W$ generated by other tenants (e.g., NRF) upon closure of the RWMC LLW disposal operations...LLW management includes development of on/offsite $L L W$ disposal capability and the supporting infrastructure."
\end{abstract}

To prevent a disposal capability gap that would occur following closure of the RWMC disposal vaults, INL must have the capability to disposition remote-handled LLW by the end of FY 2015. Following closure of the RWMC disposal vaults, INL will not have an onsite disposal facility that can dispose of remote-handled LLW generated as part of ongoing NE and NR operations. Additionally, the capability (i.e., physical infrastructure to prepare for offsite shipment and transportation systems) to dispose of all remote-handled LLW offsite does not currently exist. Without disposal capability for remote-handled LLW, current and future missions involving NE and NR operations will be impacted. Continued operation of the ATR relies on refueling of the reactor core which results in the generation of remote-handled activated metals. These metals are currently stored in the ATR canal which has limited storage capacity. If a permanent disposal capability is not established, continued operation of the ATR in support of critical NE and NR missions will be impacted. Remote-handled LLW is also generated during the post-irradiation examination of irradiated materials at the Materials and Fuels Complex (MFC), requiring permanent disposal capability. A gap in remote-handled LLW disposal capability would have a significant impact on the Naval Nuclear Propulsion Program. With a maximum NRF interim storage capacity of only 2 years, the processing of spent fuel from the Navy's nuclear-powered fleet would be significantly impacted if replacement remote-handled LLW capability is not established.

In accordance with DOE O 435.1, the DOE Field Element Manager is responsible for ensuring a process is developed and implemented for identifying the generation of radioactive waste with no identified path to disposal. The DOE Field Element Manager also is responsible for reviewing and approving the conditions under which radioactive waste with no identified path to disposal may be generated. LLW streams with no identified path to disposal will be generated only in accordance with approved conditions, which, at a minimum, will address: (a) programmatic need to generate the waste; (b) characteristics and issues preventing disposal of the waste; (c) safe storage of the waste until disposal 
can be achieved; and (d) activities and plans for achieving final disposal of the waste. Failure to establish replacement remote-handled LLW disposal capability would result in NE and NR generation of remote-handled LLW with no identified path to disposal. Limited storage capacity, coupled with potential stakeholder concerns regarding DOE waste management activities at INL, would significantly impact DOE's missions at INL.

The purpose of the INL Remote-Handled LLW Disposal Project is to establish uninterrupted remote-handled LLW disposal capability for INL. Because operations cannot be modified to eliminate remote-handled LLW generation and because interim storage capacity for remote-handled LLW is limited, it is imperative for the future of INL that replacement disposal capability be established. Approval to proceed with project development and authorization of necessary funds is critical, especially considering the required time to develop remote-handled LLW disposal capabilities. The project will ensure that modernization investments and continuing DOE mission operations are not adversely impacted by upsets resulting from insufficient waste management capability.

\subsection{Project Understandings and Assumptions}

The INL Remote-Handled LLW Disposal Project is based on the following understandings and assumptions. These criteria establish the basis from which the project has been defined.

- $\quad$ Necessary funding will be available within the timeframe necessary to ensure uninterrupted remote-handled LLW disposal capability

- $\quad$ The project will be based on development and approval as a line item project per DOE O 413.3A, "Program and Project Management for the Acquisition of Capital Assets"

- Critical decisions (CDs) will be approved in time to ensure uninterrupted remote-handled LLW disposal capability

- $\quad$ Remote-handled LLW to be managed by the project will have typical contact exposure rates up to $30,000 \mathrm{R} / \mathrm{hr}$

- A tailored approach to meeting safety-based requirements of DOE O 413.3A will be applied to meet the requirements of the newly issued DOE-STD-1189-2008, "Integration of Safety into the Design Process"

- $\quad$ RWMC closure activities will continue as currently planned, allowing continued disposal of remote-handled LLW generated at INL in the SDA disposal vaults through FY 2015

- $\quad$ Existing NEPA documentation supports a DOE decision to proceed with development of a new onsite remote-handled LLW disposal facility or disposal offsite; an environmental assessment will be prepared that evaluates impacts of the onsite disposal alternatives, offsite disposal alternatives, and a no action alternative, and identifies a specific INL location(s) for the new disposal facility if a new onsite disposal facility is pursued

- $\quad$ The project will not be impacted by the DOE complex-wide investigation of alternatives for disposal of greater-than-Class-C waste, as identified in the Notice of Intent to Prepare an Environmental Impact Statement for the Disposal of Greater-Than-Class-C Low-Level Radioactive Waste (72 FR 40135) 
- $\quad$ The project will initially address INL and tenant-generated remote-handled LLW volumes generated following closure of the RWMC disposal vaults through established milestones under the Idaho Settlement Agreement (i.e., between FY 2016 and FY 2035), with consideration given to future remote-handled LLW generation

- The project will not be impacted by changes in regulations or unanticipated litigation.

\subsection{Project Support of Department of Energy Goals}

DOE's overarching mission is to advance the national, economic, and energy security of the United States; to promote scientific and technological innovation in support of that mission; and to ensure environmental cleanup of the national nuclear weapons complex. DOE's strategic goals to achieve this mission are designed to deliver results along the following five strategic themes:

1. Energy Security: Promoting America's energy security through reliable, clean, and affordable energy

2. Nuclear Security: Ensuring America's nuclear security

3. Scientific Discovery and Innovation: Strengthening U.S. scientific discovery, economic competitiveness, and improving quality of life through innovations in science and technology

4. Environmental Responsibility: Protecting the environment by providing a responsible resolution to the environmental legacy of nuclear weapons production

5. Management Excellence: Enabling the mission through sound management.

Within these five themes are 16 strategic goals, as documented in DOE's Strategic Plan (DOE 2006), that are designed to help DOE successfully achieve its mission and vision. The INL Remote-Handled LLW Disposal Project will support achievement of the following DOE strategic goals by establishing the necessary waste disposal capability to support current and future DOE programs at INL:

- Increase U.S. energy options and reduce dependence on oil, thereby reducing vulnerability to disruption and increasing the flexibility of the market to meet U.S. needs (Goal 1.1)

- $\quad$ Prevent acquisition of nuclear and radiological materials for use in weapons of mass destruction and in other acts of terrorism (Goal 2.2)

- $\quad$ Provide safe, militarily effective nuclear propulsion plants to the U.S. Navy (Goal 2.3)

- $\quad$ Deliver scientific facilities, train the next generation of scientists and engineers, and provide laboratory capabilities and infrastructure required for U.S. scientific primacy (Goal 3.2)

- Manage DOE's post-closure environmental responsibilities and ensure future protection of human health and the environment (Goal 4.2)

- $\quad$ Build, modernize, and maintain facilities and infrastructure to achieve mission goals and ensure a safe and secure workplace (Goal 5.3). 
Establishment of continued INL remote-handled LLW disposal capability also supports the DOE's vision for INL to become "the preeminent, internationally-recognized nuclear energy research, development, and demonstration laboratory."

\subsection{Impact If Proposed Mission is Not Approved}

Completion of this project is critical to the long-term conduct of DOE's missions at INL. Following are some impacts if the Remote-Handled LLW Disposal Project is not approved:

- Continued processing of the Navy's spent fuel will be significantly impacted once existing interim storage capacity is exhausted, impacting DOE's ability to support the Navy's nuclear powered fleet

- $\quad$ Processing of spent fuel currently in storage at NRF will be negatively impacted, jeopardizing DOE's ability to comply with terms of the Idaho Settlement Agreement (State of Idaho 1995; State of Idaho 2008)

- $\quad$ Failure to meet the terms of the Idaho Settlement Agreement could result in fines and penalties of up to $\$ 60,000$ per day and termination of Navy spent fuel receipt at INL (State of Idaho 1995; State of Idaho 2008)

- $\quad$ Continuity of INL mission-critical operations will be at risk

- Materials testing operations at ATR may be curtailed once existing interim storage capacity is exhausted

- $\quad$ Future INL nuclear programs that rely on safe, compliant, remote-handled LLW disposal will be in question

- Accumulation of high radiation materials at NRF and ATR will subject workers to increased safety and health risks

- DOE will continue to spend significant resources in identifying alternate remote-handled LLW disposal pathways, interim storage capabilities, and approaches for short-term management of INL's remote-handled LLW waste streams

- $\quad$ DOE and contractor resources will be partially diverted from mission to waste management issues.

In summary, if the proposed mission is not approved it will negatively impact the long-term viability of INL as the nation's lead nuclear energy laboratory. 


\section{CONSTRAINTS AND ASSUMPTIONS}

The following sections address project limitations, standardization and environmental, safety and health requirements, safeguards and security considerations, interfaces, costs and affordability limitations, legal and regulatory constraints, and stakeholder considerations associated with the proposed project to develop replacement remote-handled LLW disposal capability.

\subsection{Operational Limitations}

The project will be implemented in a manner that minimizes any adverse impact on ongoing and planned INL programs. The project will be planned to ensure continuous INL remote-handled LLW disposal capability. There are no unmanageable operational limitations as shown in the following list:

- $\quad$ Effectiveness and technology - Strict but well-established requirements and standards exist for handling, transporting, and disposing of remote-handled LLW. The high radiation levels associated with remote-handled LLW limit the number and type of facilities and systems that may be used to manage the waste from point of generation to point of disposal. While necessitating extra precautions in waste management activities and transport system/disposal facility design, the high radiation readings associated with remote-handled LLW do not present a fundamental technical barrier to accomplishing the INL Remote-Handled LLW Disposal Project because required technologies and systems do exist. Cask systems currently being used for INL remote-handled LLW disposal will continue to be used to the maximum extent practicable.

- Capacity-Limited alternatives currently exist for offsite disposition of all INL and tenantgenerated remote-handled LLW. The most viable offsite disposal facility, the Nevada Test Site (NTS), has sufficient capacity to accept projected INL remote-handled LLW volumes. Should DOE pursue development of a new onsite facility, a sufficient number of contractors are available for competitive bidding on a construction contract. Equipment is readily available for all activities. The forecasts for remote-handled LLW generation are adequate for planning purposes, with the understanding that future programs are not clearly defined in terms of scope or schedule, but that future remote-handled LLW disposal capability will be required to support these programs.

- $\quad$ Organizations - Efforts are being coordinated between NE and NR to ensure continued remote-handled LLW disposal capability. DOE-ID and the INL contractor also are actively involved in discussions regarding the proposed complex-wide greater-than-Class-C disposal facility to ensure efforts are coordinated and that neither DOE project negatively impacts or contradicts the other. DOE-ID and the INL contractor also are coordinating ongoing waste disposal activities with EM closure activities for RWMC.

- $\quad$ Special considerations - If DOE chooses to pursue a new onsite disposal facility, additional analyses (e.g., cultural resources) may be required before construction, depending on the specific INL location sited for the new disposal facility. Waste inventories and characteristics will be reviewed/confirmed as the project progresses to ensure that analyses supporting the remote-handled LLW disposal are bounding. Offsite disposal of INL and tenant-generated remote-handled LLW may require the involvement of the Nuclear Regulatory Commission, U.S. Environmental Protection Agency, State of Idaho, and other potentially impacted stakeholders. 


\subsection{Environmental, Geographic, and Organizational Limitations}

Disposal of INL and tenant-generated remote-handled LLW is currently constrained by DOE decisions documented in the 1995 Programmatic Spent Fuel and Waste Management ROD (60 FR 28680) and the 2000 Waste Management ROD (65 FR 10061). Should DOE pursue a new onsite disposal facility, the location for the facility will be constrained by DOE and applicable regulatory and performance-based requirements and standards. Potentially limiting characteristics of the proposed location that would need to be considered include geology, soils, surface and subsurface hydrology, flora and fauna, archeological resources, seismic, and planned land use. A radiological performance assessment and composite analysis would be required to demonstrate that there is a reasonable expectation that the performance objectives of DOE O 435.1 would be met. The resulting DOE Headquarters-issued disposal authorization statement would specify limits and conditions on construction, design, operations, and closure of the remote-handled LLW disposal facility.

\subsection{Standardizations and Standards Requirements}

This project must conform to applicable DOE orders, guidance, and other requirements. The project will comply with other applicable industry standards, requirements as identified in laws, regulations, and DOE directives. Applicable codes and standards for the project will be specified in a technical and functional requirements document(s); additional standards and requirements defined during project planning will be specified in final design and work plan documents.

\subsection{Environmental, Safety, and Health Requirements}

This section includes descriptions of the regulatory framework that drives environmental, safety, and health requirements and highlights unique project requirements.

\subsubsection{National Environmental Policy Act}

Disposal of INL and tenant-generated remote-handled LLW is currently constrained by DOE decisions on waste management documented in the 1995 Programmatic Spent Fuel and Waste Management ROD (60 FR 28680) and the 2000 Waste Management ROD (65 FR 10061).

The 1995 ROD on Programmatic Spent Nuclear Fuel Management and Idaho National Engineering Laboratory Environmental Restoration and Waste Management Programs (60 FR 28680) supported development of a new onsite remote-handled LLW disposal facility. The ROD specifically states that INL-generated LLW "will be treated onsite and offsite and disposed of onsite." The associated environmental impact statement addressed the impacts of design, construction, and operation of a new, permanent radioactive waste disposal facility to be located at an existing site or at a previously undisturbed site at INL. Regarding this project, referred to as the Mixed/LLW Disposal Facility Project, the ROD indicates that decisions regarding this (and other identified projects) would be made in the future pending further project definition, funding priorities, and any further appropriate review under NEPA (42 USC 4321 et seq. 1969). Stakeholder comments on the Programmatic Spent Nuclear Fuel Management and Idaho National Engineering Laboratory Environmental Restoration and Waste Management Programs Environmental Impact Statement (DOE 1995) were considered in making the decision to allow for continued onsite disposal of LLW at INL.

In addition, the 2000 ROD for DOE's Waste Management Program: Treatment and Disposal of Low-Level and Mixed Low-Level Waste (65 FR 10061) established DOE's decision to perform minimum waste treatment at all sites; to continue, to the extent practicable, disposal of LLW onsite at INL, the Los 
Alamos National Laboratory in New Mexico, the Oak Ridge Reservation in Tennessee, and the Savannah River Site in South Carolina; and to conduct disposal of LLW from offsite generators at Hanford and NTS. The ROD indicates that INL and the Savannah River Site will continue to dispose of LLW generated by the Naval Nuclear Propulsion Program. The decision also did not preclude DOE sites from using commercial disposal facilities. Stakeholder comments on the Waste Management Programmatic Environmental Impact Statement (DOE 1997) were considered in making the decision to allow for a combination of LLW disposal alternatives, including continued onsite disposal of LLW at INL and shipment and disposal offsite.

Establishment of replacement capability for disposal of remote-handled LLW also could address future stakeholder concerns associated with future reactor and nuclear fuel-cycle research and development programs at INL. Stakeholder groups take issue with DOE generation of radioactive waste with no path to disposal. Through establishment of continued compliant disposal capability for this waste, the risk associated with long-term interim storage pending identification of an appropriate disposal facility can be mitigated, thereby increasing the viability of future DOE projects and programs at INL.

During project development, the appropriate NEPA analysis will be conducted to support DOE's decision for establishing continued remote-handled LLW disposal capability. The NEPA analysis will include an evaluation of the impacts on the human environment for the proposed action, reasonable alternatives to the proposed action, and the no action alternative. This analysis will ensure that potential environmental impacts are evaluated and documented. The NEPA process is followed to arrive at a federal decision.

\subsubsection{Disposal Facility Waste Acceptance Criteria}

In order to dispose of INL and tenant-generated remote-handled LLW offsite, the waste would be required to meet the disposal facility waste acceptance criteria (WAC) and to meet all applicable requirements during transport. If DOE pursues development of a new onsite disposal facility, it will likely be sited for disposal of INL-generated remote-handled LLW only and the facility will be sited, designed, constructed, and ultimately closed in accordance with the requirements of DOE O 435.1. The resulting DOE Headquarters-issued disposal authorization statement would specify limits and conditions on construction, design, operations, and closure of the LLW disposal facility. A Nuclear Regulatory Commission license would not be required as non-DOE waste would not be accepted for disposal. A RCRA permit from the State of Idaho/U.S. Environmental Protection Agency also would not be required as the facility would not accept mixed waste.

\subsubsection{Radiation Protection}

Disposal options for remote-handled LLW must consider the high radiation levels associated with the waste. INL remote-handled LLW has typical dose rates of up to 30,000 R/hr. As such, measures and controls must be established to minimize worker and public radiological doses to as low as reasonably achievable from point of generation to point of disposal.

\subsubsection{Nuclear Safety and Hazards Analysis}

Remote-handled LLW disposal is anticipated to be managed as a Hazard Category 2 activity. In accordance with the requirements of DOE O 413.3A, safety must be integrated into the design process for new or major modifications to DOE Hazard Category 1, 2, and 3 nuclear facilities. The intended purpose of this requirement involves the handling of hazardous materials, both radiological and chemical, in a way that provides adequate protection to the public, workers, and the environment. Requirements provided in DOE O 413.3A and DOE O 420.1B, "Facility Safety," and the expectations of DOE-STD-1189-2008, 
"Integration of Safety into the Design Process," provide for identification of hazards early in the project and use of an integrated team approach to design safety into the facility.

Hazardous material inventories associated with INL remote-handled LLW are very low in comparison to other nuclear operations and are commensurate with existing RWMC remote-handled LLW disposal operations. No chemicals found in the Occupational Safety and Health Administration substance-specific standards have been identified that would create a potential for exposure triggering medical surveillance during continued management of INL remote-handled LLW. Additionally, no highly hazardous chemicals listed in 29 CFR 1910.119, "Process Safety Management of Highly Hazardous Chemicals (Appendix A, List of Highly Hazardous Chemicals, or Toxics and Reactives,)"will be generated, used, stored, or disposed of as part of continued INL remote-handled LLW management. The primary hazard associated with management of remote-handled LLW is worker exposure to the high radiation levels associated with the waste through a variety of exposure scenarios.

In addition to ensuring compliance with the requirements of DOE Order 5400.5, "Radiation Protection of the Public and the Environment," other key safety aspects associated with the INL Remote-Handled LLW Disposal Project may include compliance with Department of Transportation requirements, applicable seismic requirements, compliance with performance objectives of DOE O 435.1, compliance with disposal facility WAC, and criticality safety.

As a Hazard Category 2 nuclear activity, disposal of remote-handled LLW must meet specified nuclear safety requirements. The requisite nuclear safety documentation will be developed as part of the project. Such documentation includes a conceptual safety design report, a preliminary hazard analysis report, a preliminary safety validation report, a preliminary safety design report, a hazard analysis report, a preliminary safety validation report, the preliminary documented safety analysis report, the documented safety analysis, and the safety evaluation report. To the maximum extent practicable, project safety documentation will be based on the safety documentation for ongoing disposal operations at RWMC.

\subsection{Safeguards and Security Considerations}

INL is committed to implementing an Integrated Safeguards and Security Management System in accordance with DOE P 470.1, "Integrated Safeguards and Security Management Policy." This system ensures the scope of work is well defined, security risks are analyzed, and measures to mitigate security risks are developed and implemented. It also provides for a feedback and continuous improvement process.

Based on the nature of the INL-generated remote-handled LLW, safeguards issues associated with waste are anticipated to be minimal. The primary focus of the safeguards and security analysis to be conducted during project planning activities will be completion of a radiological sabotage analysis. Existing INL safeguards and security requirements (e.g., controlled site access) are anticipated to be sufficient to ensure worker and public safety and for property protection while the waste is onsite.

Some waste component configurations generated at NRF and ATR will most likely be "classified shapes," qualifying them as National Security Information. However, this issue will continue to be addressed during waste packaging, as is currently done. The waste streams, as received, will be self-protecting (i.e., the radiation fields presented by the unshielded materials prevent examination without protective facilities). Additionally, all materials will be sealed in a waste container (or liner) before leaving the protected areas and before shipment to the disposal facility.

All project documentation will be reviewed for classification before being issued. 


\subsection{Interfaces with Existing and Planned Acquisitions}

To successfully provide uninterrupted disposal capability for INL and tenant-generated remote-handled LLW, the chosen alternative must be compatible and must interface with facilities, equipment, and operating procedures currently in use at the generating facilities or only require minor modifications. Continuing use of functional and efficient equipment reduces cost, simplifies the project, and improves safety of remote-handled LLW management. The primary project interface is via the transport casks used to ship waste from the generator to the disposal facility. The project will work closely with the generating facilities to ensure compatibility of any new waste transport system(s) with current operations.

\subsection{Affordability Limits on Investment}

A specific limit on investment has not been established by DOE. However, it is DOE's objective to develop remote-handled LLW disposal capability in an economical manner, favorably balancing the projected capital costs against life-cycle costs. No technology development is anticipated for the project.

\subsection{Goals for Limitations on Recurring or Operating Costs}

INL intends to make waste management decisions that will ensure cost-effective disposal of remote-handled LLW generated at INL, continue sound management of remote-handled LLW disposal activities, and minimize major modifications to existing generator facilities. This approach will ensure uninterrupted support of INL operations and research activities for accomplishment of DOE missions and goals. While onsite disposal of INL-generated remote-handled LLW may be recommended as the preferred approach, certain waste streams may be better suited for disposal offsite (e.g., waste streams that do not meet facility WAC). In such cases, a combination of onsite and offsite remote-handled LLW disposal may be implemented.

The project will utilize experience from ongoing remote-handled LLW management to capitalize on operational efficiencies and lessons-learned from current disposal activities, thereby resulting in reduced life-cycle costs to DOE.

\subsection{Legal and Regulatory Constraints and Requirements}

No special legal issues or regulatory constraints are anticipated for this project. The project will be conducted in full compliance with applicable federal, state, and local requirements. Stakeholder review of NEPA documentation will ensure that NEPA values are addressed.

\subsection{Stakeholder Considerations}

Project support from local and regional nongovernment organizations (e.g., Snake River Alliance) is expected to be mixed depending on DOE's proposed path forward. Local stakeholder groups are expected to support continued preparation of Navy spent nuclear fuel for shipment from the State of Idaho, in accordance with the terms of the Idaho Settlement Agreement (State of Idaho 1995; State of Idaho 2008). However, these same groups also would likely oppose establishment of a new onsite remote-handled LLW disposal facility because of INL's location above the Snake River Plain Aquifer. For offsite disposal options, similar stakeholder groups affected by transportation and ultimate disposal would likely have similar concerns. Stakeholder considerations will be addressed as part of the NEPA process, which will provide opportunity for comment on DOE's proposed action. In addition to a formal 
public comment period, stakeholder input also will be solicited via a series of public meetings and forums.

\subsection{Limitations}

No significant limitations are associated with program structure, competition and contracting, or streamlining project implementation. Current waste management processes and experience will be used as a basis for initial project planning to capitalize on lessons learned and efficiencies of existing remotehandled LLW disposal operations; there is no need for prototypes. No new technology development is anticipated. Necessary technical resources (both in-house and subcontract) are available to support the project. An integrated project team will provide direction and oversight in areas of project management, program operations, budget, finance, contracting, safety, environment, engineering, and quality during the project.

\subsection{Risk Management Process}

The Remote-Handled LLW Disposal Project risk management process will follow the requirements of DOE O 413.3A and DOE M 413.3-1, "Project Management for the Acquisition of Capital Assets." The risk management process will be analytical in nature and tailored based on a logical, deterministic, comprehensive identification of critical technical, scope, schedule, and cost risks. The integrated project team will develop an effective risk management process involving the following components, which will be continually reevaluated and revised, as necessary, throughout the project life cycle:

- A risk management plan

- $\quad$ Programmatic system, functional, and technical requirements

- $\quad$ Feasible, stable, well-understood user requirements

- $\quad$ Close coordination with NE and NR program missions

- $\quad$ Planned and structured risk management process, integral to the acquisition process

- $\quad$ Acquisition strategy consistent with risk level and risk-handling strategies

- $\quad$ Defined set of performance criteria for all performance scope, schedule, and cost elements

- $\quad$ Metrics to monitor effectiveness of risk-handling strategies

- $\quad$ Effective test, checkout, startup/turnover, and project closeout plans

- $\quad$ Formal documentation and information handoff among the parties.

As appropriate, these components will be addressed within the NE program, project planning, execution, and budget activities. Table 2 identifies initial project risks by general risk category that, if not addressed, could impact the project's expected outcome. The project risk management plan will provide a quantitative assessment of all identified risks. 
Table 1. Potential risk categories.

\begin{tabular}{|c|c|c|}
\hline Risk Category & Identified Risk & Mitigation \\
\hline Project definition & $\begin{array}{l}\text { SDA disposal operations } \\
\text { cease before the end of } \\
\text { FY } 2015\end{array}$ & $\begin{array}{l}\text { Close coordination with EM to ensure continued } \\
\text { disposal operations of remote-handled LLW; } \\
\text { advanced notice of DOE's decision that allows } \\
\text { adequate time to accelerate project or identify } \\
\text { interim storage measures until such time as a } \\
\text { new disposal facility is operational }\end{array}$ \\
\hline $\begin{array}{l}\text { Environmental, safety, } \\
\text { and health }\end{array}$ & $\begin{array}{l}\text { NEPA analysis does not } \\
\text { result in a finding of no } \\
\text { significant impact, which } \\
\text { requires development of an } \\
\text { environmental impact } \\
\text { statement and ROD }\end{array}$ & $\begin{array}{l}\text { Early and open communication with } \\
\text { stakeholders on project definition; early } \\
\text { development of siting study and appropriate } \\
\text { criteria to select an onsite location that has } \\
\text { minimal impact to the environment; } \\
\text { environmental impacts previously assessed as } \\
\text { part of two separate waste management RODs }\end{array}$ \\
\hline $\begin{array}{l}\text { Acquisition } \\
\text { management }\end{array}$ & $\begin{array}{l}\text { Poorly defined requirements } \\
\text { for acquisition of project } \\
\text { resources }\end{array}$ & $\begin{array}{l}\text { Development of a comprehensive acquisition } \\
\text { strategy and planning, and use of INL-specific } \\
\text { and complex-wide lessons learned }\end{array}$ \\
\hline Project management & $\begin{array}{l}\text { Inadequate management } \\
\text { control }\end{array}$ & $\begin{array}{l}\text { Clearly identified roles and responsibilities in } \\
\text { the project execution plan and selection of } \\
\text { qualified personnel to fill those rolls }\end{array}$ \\
\hline $\begin{array}{l}\text { Funding and budget } \\
\text { management }\end{array}$ & $\begin{array}{l}\text { Inadequate funding not } \\
\text { allowing establishment of } \\
\text { remote-handled LLW } \\
\text { disposal capability by the } \\
\text { end of FY 2015, causing } \\
\text { cost overruns and impacting } \\
\text { ongoing operations }\end{array}$ & $\begin{array}{l}\text { Appropriate planning, cost estimating, and } \\
\text { budgeting submittals to DOE Headquarters } \\
\text { during the CD process and continuous updates } \\
\text { during project execution; implement cost-saving } \\
\text { acquisition strategies and proper contractor } \\
\text { controls; early development of DOE O } 435.1 \\
\text { documentation for an onsite facility to ensure } \\
\text { identification of all design, siting, and } \\
\text { construction requirements; concurrent } \\
\text { development of required NEPA documentation } \\
\text { with DOE O } 435.1 \text { documentation to ensure that } \\
\text { project does not pose an unacceptable risk to the } \\
\text { environment }\end{array}$ \\
\hline $\begin{array}{l}\text { Technology and } \\
\text { engineering } \\
\text { management }\end{array}$ & $\begin{array}{l}\text { Inadequate development of } \\
\text { design }\end{array}$ & $\begin{array}{l}\text { Using lessons learned from ongoing INL } \\
\text { remote-handled LLW disposal operations }\end{array}$ \\
\hline $\begin{array}{l}\text { Project schedule } \\
\text { development }\end{array}$ & $\begin{array}{l}\text { Failure to identify critical } \\
\text { path activities that affect the } \\
\text { completion schedule }\end{array}$ & $\begin{array}{l}\text { Proper planning through integrated project team } \\
\text { and coordination with external programs that } \\
\text { affect schedule }\end{array}$ \\
\hline $\begin{array}{l}\text { Project cost estimate } \\
\text { and development }\end{array}$ & $\begin{array}{l}\text { Inadequate cost estimating } \\
\text { and contingency analysis }\end{array}$ & $\begin{array}{l}\text { Upfront characterization, planning, and risk } \\
\text { identification to provide estimates within the } \\
\text { boundaries of contingency range }\end{array}$ \\
\hline
\end{tabular}


Table 1. (continued).

\begin{tabular}{lll}
\hline \multicolumn{1}{c}{ Risk Category } & \multicolumn{1}{c}{ Identified Risk } & \multicolumn{1}{c}{ Mitigation } \\
\hline $\begin{array}{l}\text { Project interface and } \\
\text { integration }\end{array}$ & $\begin{array}{l}\text { Inadequate coordination } \\
\text { with other programs, } \\
\text { stakeholders, and DOE } \\
\text { Headquarters entities }\end{array}$ & $\begin{array}{l}\text { Top-down management to integrate mission, } \\
\text { schedule, and funding requirements and } \\
\text { maintenance of key contacts and communication } \\
\text { at appropriate levels }\end{array}$ \\
$\begin{array}{l}\text { Policy and } \\
\text { stakeholders }\end{array}$ & $\begin{array}{l}\text { Lack of support from State } \\
\text { of Idaho and other } \\
\text { stakeholders }\end{array}$ & $\begin{array}{l}\text { Early communication with stakeholders to } \\
\text { identify and address concerns }\end{array}$ \\
Project location & $\begin{array}{l}\text { Suitable onsite location for } \\
\text { disposal facility cannot be } \\
\text { identified }\end{array}$ & $\begin{array}{l}\text { Completion of siting study and site selection } \\
\text { through the NEPA process to minimize potential } \\
\text { impact to the environment }\end{array}$ \\
& $\begin{array}{l}\text { Conflicts with greater-than- } \\
\text { Class-C environmental } \\
\text { impact statement, including } \\
\text { potential segmentation and } \\
\text { stakeholder perceptions }\end{array}$ & $\begin{array}{l}\text { Close coordination with DOE Headquarters staff } \\
\text { to ensure that same waste streams are not } \\
\text { identified for both facilities; clear definition that } \\
\text { proposed greater-than-Class-C facility is } \\
\text { separate from INL remote-handled LLW } \\
\text { disposal facility }\end{array}$ \\
\hline
\end{tabular}




\section{APPLICABLE CONDITIONS AND INTERFACES}

The INL Remote-Handled LLW Disposal Project must obtain CD-4, Approve Start of Operations, approval by the end of FY 2015 to ensure continued, uninterrupted remote-handled LLW disposal capability. The project will be closely integrated with INL and NRF operations to ensure mission execution is not impacted. Upon recommendation of the path forward for the project, planning activities will be integrated with applicable operations personnel to ensure operational considerations are incorporated into project requirements. As new INL programs develop, waste management activities will be closely coordinated to ensure the most cost-effective and efficient waste disposal practices are implemented and that generator-disposal facility interfaces and requirements are clearly defined and accounted for.

\subsection{Significant Conditions}

The most significant conditions affecting the project are the planned closure of the SDA; high radiation levels associated with INL and tenant-generated remote-handled LLW; lack of sufficient interim storage capacity to address a disposal capability gap greater than 2 years; and the affect of remote-handled LLW disposal capability on ongoing and future programs at INL. The status of INL remote-handled LLW disposal capability, planning programs, and interfaces that affect the Remote-Handled LLW Disposal Project are described in Section 1.

\subsection{Method of Accomplishment}

The Remote-Handled LLW Disposal Project will implement an acquisition strategy that will be cost-effective in meeting DOE's goals and missions and the Remote-Handled LLW Disposal Project objectives. A stand-alone acquisition strategy document will be prepared that defines the specific strategy that will be implemented for the highest ranked alternative. The project also will ensure all applicable conditions and interfaces are described and managed in compliance with DOE O 413.3A. Project activities will be implemented using readily available materials, equipment, and processes. To the extent practicable, required documentation and analyses will build on existing documentation for remote-handled LLW disposal operations in the SDA. Management oversight will be accomplished using INL's formal project management structure.

\subsection{Cooperative Opportunities}

Coordination between NE and NR will be a key element for success of the Remote-Handled LLW Disposal Project. NE will be the lead DOE organization responsible for the INL Remote-Handled LLW Disposal Project. NE will coordinate activities with NR to ensure the project is implemented in a way that minimizes impacts to both NE and NR programs at INL. Although acquisition authority resides with NE-1, NR fully participates in development of the project and concurrence of critical decisions.

In addition, lessons learned from historical operation of the SDA will be incorporated into project planning activities. 


\section{RESOURCE REQUIREMENTS AND SCHEDULE}

This section provides the timeline for implementation, funding and resource requirements, and performance metrics associated with the proposed project to establish continued, uninterrupted remote-handled LLW disposal capability.

\subsection{Timeline}

The CD timeframe for the INL Remote-Handled LLW Disposal Project is FY 2008 to FY 2015. To support continued, uninterrupted remote-handled LLW disposal capability, CD-4 must be obtained by the end of FY 2015 when the current disposal capability at RWMC is planned to cease. Other CD milestones must support an end of FY 2015 project completion date.

In accordance with DOE O 413.3A, a tailored approach to meeting various requirements may be implemented based on the complexity, cost, and risks of the project. Requirements will be addressed to the extent necessary and practical for managing the project. In general, tailoring may involve consolidation of decisions, documentation, substituting equivalent documents, concurrency of processes, "bundling" similar projects together, or creating a portfolio of projects to facilitate a single CD, acquisition strategy, and so forth for the entire group of projects. Tailoring also may include adjusting the scope of independent project reviews and external independent reviews to match the size, risk, and complexity of the projects being reviewed.

\subsection{Cost Range and Measures of Success}

The preliminary estimated cost range of identified alternatives for this project (i.e., total project cost) is approximately $\$ 30$ to $\$ 80$ million. The life-cycle cost of the project is estimated at $\$ 130$ to $\$ 660$ million. Capital project costs (i.e., total project cost) would be realized through FY 2015. Operations and maintenance costs would be realized between FY 2016 and FY 2035.

NE will be the lead DOE organization responsible for the INL Remote-Handled LLW Disposal Project. NE will coordinate activities with NR. The following are key measures of success for the project:

- Revisions to scope and schedule described in the project baseline are minimized

- $\quad$ Remote-handled LLW disposal capability will be in place by the end of FY 2015

- $\quad$ Stakeholders accept project implementation strategy

- $\quad$ Project resources are available and delivered on schedule to support project implementation.

\subsection{Resource Requirements}

The proposed timeline (shown below) is based on planned cessation of remote-handled LLW disposal capability in the SDA.

CD-0 Approve Mission Need

CD-1 Approve Preliminary Baseline Range

CD-2/3A Approve Performance Baseline and Authorization to Execute

CD-3B Approve Start of Construction

CD-4 Approve Start of Operations
June 2009

March 2010

October 2011

July 2012

September 2015 
Internal (i.e., DOE-ID and INL contractor) resources will be required for document preparation. Cost estimating, scheduling, reviews, and regulatory analysis also will be required. Sufficient internal resources are available to support the project. In cases where additional support is required, subcontract resources with relevant qualifications and experience will be used.

\subsection{Performance Metrics}

Performance measurement is mandated by the Government Performance and Results Act of 1993. The INL Remote-Handled LLW Disposal Project performance measurement criteria will be managed in accordance with DOE O 413.3A. The project will follow applicable DOE project and program management requirements such as the energy system acquisition and approval board reviews, earned value management system, and project analysis and reporting system.

The INL Remote-Handled LLW Disposal Project will measure and control cost and schedule performance using an earned value management system based on the American National Standard Institute/Electronic Industries Alliance Earned Value Management Systems (ANSI/EIA-748-A-1998) guidelines. The preliminary project execution plan will define detailed performance metrics. Technical, schedule, and cost baseline parameters will be controlled through formal change control procedures.

The INL Remote-Handled LLW Disposal Project will be considered complete when replacement remote-handled LLW disposal capability is in place. 


\section{DEVELOPMENT PLAN}

This section summarizes previous planning efforts that have occurred to date and describes incorporation of those plans into this project, summarizes milestones for CDs, identifies the INL Remote-Handled LLW Disposal Project concept development and approach, and provides an overview of the management approach for implementation of the project.

\subsection{Planning and Coordination with Current Programs Efforts}

The project will benefit from operations experience gained from current, ongoing onsite remote-handled LLW disposal operations. The objective of the INL Remote-Handled LLW Disposal Project is to provide uninterrupted, remote-handled LLW disposal capability to NE and NR programs at INL. The majority of project planning efforts, to date, have focused on identifying potentially viable disposal alternatives that will not negatively impact ongoing operations. Moving forward, planning efforts will focus on ensuring a smooth transition between remote-handled LLW disposal at the existing SDA disposal vaults and the new disposal capability.

\subsection{Activities and Schedule to Meet Milestones and Critical Decisions}

Because of the maturity of the requirements, lack of complexity, and cost and schedule knowledge gained from ongoing remote-handled LLW disposal operations at INL, tailored CD packages are anticipated to be developed for the project. A more detailed breakdown of the $\mathrm{CD}$ phasing documentation will be provided in the project's preliminary project execution plan. The following discussion summarizes the CD timeline for the project.

The period of performance for the planning phase of the INL Remote-Handled LLW Disposal Project began in FY 2007. Project planning and technical and administrative support began in FY 2007. Planning will continue and be expanded (pending budget authority) throughout the project life cycle. The project will end when all activities necessary to continue disposal operations are complete (no later than end of FY 2015).

\subsection{Concept Development Approach and Expected Outcome}

The INL Remote-Handled LLW Disposal Project will provide replacement remote-handled LLW disposal capability for ongoing and future programs at INL. The proposed strategy promotes continued development of the NE mission at INL, continued support of the Naval Nuclear Propulsion Program, and responsible, sound waste management by DOE.

\subsection{Management Approach}

Management of the INL Remote-Handled LLW Disposal Project will follow structured management practices and use a formal, accountable project control process. The DOE-ID Assistant Manager of Infrastructure is the Site Project Director responsible for defining scope of the project and ultimately establishing management infrastructure for planning, procurement, and oversight of INL waste management actions. The proposed management structure includes a single Federal Project Director reporting to the Site Project Director. The Site Project Director and Federal Project Director have support from appropriate internal DOE and INL contractor procurement, legal, environmental safety and health, safeguards and security, and administrative staff. INL contractor project management personnel will 
report directly to the Federal Project Director during implementation of the project. More information on the management structure of the project will be provided in the preliminary project execution plan. 


\section{CLOSING STATEMENT}

Establishment of replacement remote-handled LLW disposal capability will help DOE ensure continuity of ongoing NE and NR programs at INL, provide necessary waste management infrastructure to support DOE's commitments under the Idaho Settlement Agreement (State of Idaho 1995; State of Idaho 2008), and provide waste management infrastructure to support future mission-related INL programs. Project functions and requirements of the project are well known and a reasonable cost and schedule range has been established for the project. Because of multiple DOE missions at INL, the INL Remote-Handled LLW Disposal Project is a unique project where NE and NR missions are integrated to fulfill DOE's strategic goals of protecting our environment, national defense assets, energy strategy, and economic security to support our human capital and competitive edge. Simply put, failure to proceed with the INL Remote-Handled LLW Disposal Project would significantly impede DOE's ability to meet established commitments with the State of Idaho and would put the future of INL as the DOE's lead nuclear energy laboratory in question. 


\section{REFERENCES}

10 CFR 830, "Nuclear Safety Management," Code of Federal Regulations, Office of the Federal Register, February 4, 2002.

10 CFR 835, "Occupational Radiation Protection," Code of Federal Regulations, Office of the Federal Register, July 11, 2007.

10 CFR 851, "Worker Safety and Health Program," Code of Federal Regulations, Office of the Federal Register, November 30, 2006.

29 CFR 1910, "Occupational Safety and Health Standards," Code of Federal Regulations, Office of the Federal Register, February 15, 2008.

29 CFR 1926, "Safety and Health Regulations for Construction," Code of Federal Regulations, Office of the Federal Register, February 15, 2008.

60 FR 28680, 1995, Record of Decision for the Spent Nuclear Fuel and Idaho National Engineering Laboratory Environmental Restoration and Waste Management EIS, Federal Register.

65 FR 10061, 2000, Record of Decision for the Department of Energy's Waste Management Program and Disposal of Low-Level Waste and Mixed Low-Level Waste: Amendment of the Record of Decision for the Nevada Test Site, Federal Register, February 2000.

72 FR 40135, Notice of Intent to Prepare an Environmental Impact Statement for the Disposal of Greater-Than-Class-C Low-Level Radioactive Waste, Federal Register.

15 USC§ 2001 et seq., “Toxic Substances Control Act,” United States Code.

42 USC § 4321 et seq., "National Environmental Policy Act of 1969 (NEPA)," United States Code, January 1970.

42 USC § 6921 et seq., "Identification and Listing of Hazardous Waste," United States Code, 1984.

42 USC § 9601 et seq., "Comprehensive Environmental Response, Compensation, and Liability Act (CERCLA)," United States Code, January 2006.

ANSI/EIA-748-A, 1998, "Earned Value Management Systems," American National Standards Institute, June 1998.

DOE, 1995, Programmatic Spent Nuclear Fuel (SNF) and Idaho National Engineering Laboratory (INEL) Environmental Restoration and Waste Management EIS, DOE/EIS-0203-F, U.S. Department of Energy, April 1995.

DOE, 1997, Final Waste Management Programmatic Environmental Impact Statement For Managing Treatment, Storage, and Disposal of Radioactive and Hazardous Waste, DOE/EIS-0200-F, Office of Environmental Management, U.S. Department of Energy, May 1997.

DOE, 2006, U.S. Department of Energy Strategic Plan, Office of Program and Analysis Evaluation, U.S. Department of Energy. 
DOE-ID, 1999, Final Record of Decision: Idaho Nuclear Technology and Engineering Center: Operable Unit 3-13, DOE/ID-10660, Rev. 0, Idaho National Laboratory, October 1999.

DOE-ID, 2004, Federal Task Force Report-Assessment of Options for Future Disposal of Low-Level Radioactive Waste Generated at the Idaho National Engineering and Environmental Laboratory, Letter Report TPO-TRA-03-025, March 17, 2004.

DOE-ID, 2007, ICDF Complex Waste Acceptance Criteria, DOE/ID-10881, Rev. 4, Idaho National Laboratory, July 2007.

DOE M 413.3-1, "Project Management for the Acquisition of Capital Assets," U.S. Department of Energy, March 28, 2003.

DOE-NV, 1999, Agreement in Principal Between the Department of Energy and the State of Nevada, DE-GM08-99NV13571, June 1999.

DOE O 413.3A, "Program and Project Management for Acquisition of Capital Assets," U.S. Department of Energy, July 28, 2006.

DOE O 420.1B, “Facility Safety,” U.S. Department of Energy, December 22, 2005.

DOE O 435.1, "Radioactive Waste Management," Change 1, U.S. Department of Energy, July 9, 1999.

DOE O 440.1A, "Worker Protection Program for DOE (Including the National Nuclear Security Administration) Federal Employees," U.S. Department of Energy, May 17, 2007.

DOE P 450.4, “Safety Management System Policy,” U.S. Department of Energy, October 15, 1996.

DOE P 450.7, "Environment, Safety and Health (ESH) Goals," U.S. Department of Energy, August 2, 2004.

DOE P 470.1, "Integrated Safeguards and Security Management (ISSM) Policy," U.S. Department of Energy, May 8, 2001.

DOE STD 1189-2008, "Integration of Safety into the Design Process," U.S. Department of Energy, March 2008.

INL, 2006, “Low-Level Waste Disposal Alternatives," INL/EXT-06-11601, Revision 1, Idaho National Laboratory, September 2006.

State of Idaho, 1983, "Hazardous Waste Management," Idaho Statute, Title 39, "Health and Safety," Chapter 44, "Hazardous Waste Management" (also known as the Hazardous Waste Management Act of 1983).

State of Idaho, 1995, "Settlement Agreement and Consent Order to fully resolve all issues in the actions Public Service Co. of Colorado v. Batt, No. CV 91-0035-S-EJL (D. Id.) and United States v. Batt, No. CV-91-0065-S-EJL (D. Id.)," Executed October 16, 1995.

State of Idaho, 2008, "Addendum to the Settlement Agreement and Consent Order in Public Service Co. of Colorado v. Batt, No. CV 91-0035-S-EJL (D. Id.) and United States v. Batt, No. CV-91-0054S-EJL (D. Id.)," Executed June 4, 2008. 


\section{Appendix A}

Contact and Remote-Handled Low-Level Waste Disposal 


\section{Appendix A}

\section{Contact and Remote-Handled Low-Level Waste Disposal}

\section{A-1. CONTACT AND REMOTE-HANDLED LOW-LEVEL WASTE GENERATION}

INL routinely generates contact-handled LLW (i.e., less than $200 \mathrm{mR} / \mathrm{hr}$ on contact) from facility operations and from decontamination and demolition of inactive facilities. Most of the waste is debris such as personal protective equipment, wood, plastics, cloth, glass, ferrous and nonferrous metals, concrete and piping generated from operations, maintenance, surveillance, and cleanup.

Solidified/stabilized liquids and sludge also are generated and disposed of. Contact-handled LLW comprises approximately $98 \%$ of INL LLW volume generated annually. The current annual average generation rate for contact-handled LLW is $4,000 \mathrm{~m}^{3}$, with INL generating approximately $900 \mathrm{~m}^{3} / \mathrm{yr}$, the Idaho Cleanup Project generating $1,100 \mathrm{~m}^{3} / \mathrm{yr}$, NRF generating approximately $1,050 \mathrm{~m}^{3} / \mathrm{yr}$, and the Advanced Mixed Waste Treatment Project generating approximately $950 \mathrm{~m}^{3} / \mathrm{yr}$. A significant decrease in INL contact-handled LLW generation is anticipated as EM activities at INL are completed (see Figure A-1). Based on this anticipated decrease in contact-handled LLW generation and the uncertainty associated with predicting future contact-handled LLW generation rates for new programs, a decision was made, consistent with the 1995 Programmatic Spent Fuel and Waste Management ROD (60 FR 28680) and the 2000 Waste Management ROD (65 FR 10061), to establish offsite disposal capability for all INL-generated contact-handled LLW beginning in FY 2009.



Figure A-1. Idaho National Laboratory baseline mixed and low-level waste data disposition forecast. 
Remote-handled LLW (i.e., greater than $200 \mathrm{mR} / \mathrm{hr}$ on contact) generated at INL includes resins and activated metals. Ion-exchange resins from pool and reactor operations are generated at ATR (approximately $36 \mathrm{~m}^{3} / \mathrm{yr}$ ) and from pool operations at NRF (approximately $8 \mathrm{~m}^{3} / \mathrm{yr}$ ). ATR ion-exchange resins are generated approximately four to six times annually from reactor loop and reactor ion-exchange systems. The generation rate depends on reactor operations and also varies during the years when core internal changeouts are performed. ATR produces about $3 \mathrm{~m}^{3}$ of activated metals during reactor core changeout operations, approximately every 8 years. These components require decay time before they can be handled for disposal and are currently in storage at the Reactor Technology Complex. NRF produces approximately $35 \mathrm{~m}^{3} / \mathrm{yr}$ of activated metals during routine operations. In addition, an estimated $60 \mathrm{~m}^{3}$ of activated metals are expected to be generated from new programs and from processing of co-mingled, remote-handled waste stored in the Radioactive Scrap and Waste Facility at the Materials and Fuels Complex. Figure A-2 presents current and anticipated remote-handled LLW generation rates by generator through FY 2035 based on current mission activities.

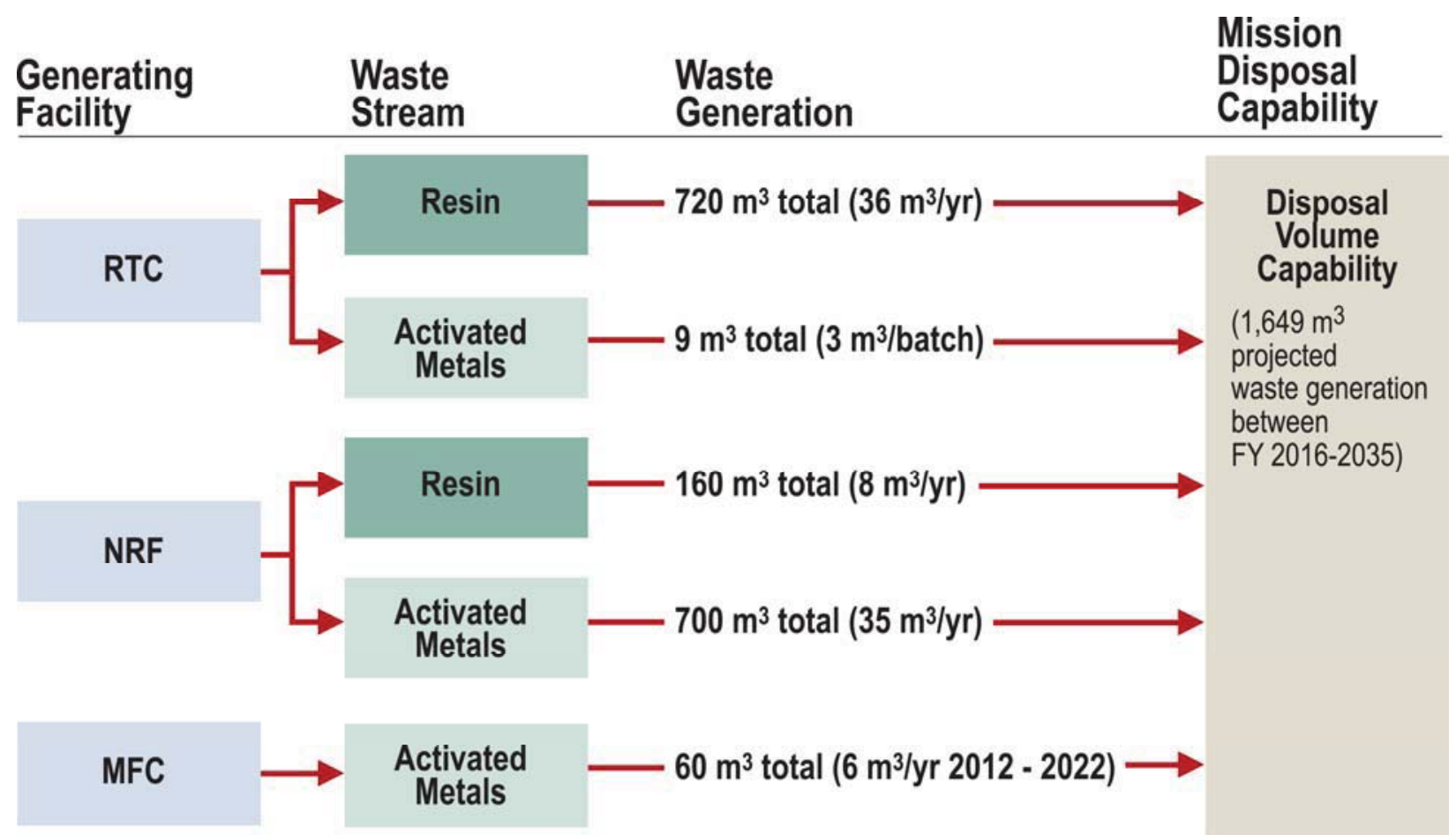

Figure A-2. Idaho National Laboratory remote-handled low-level waste generation.

\section{A-2. CURRENT ONSITE CONTACT-HANDLED AND REMOTE-HANDLED LOW-LEVEL WASTE DISPOSAL OPERATIONS}

The majority of contact and remote-handled LLW generated at INL is currently disposed of at RWMC. RWMC was created in 1952 for disposal of radioactive waste. Currently, the facility consists of three major areas: the SDA, the Transuranic Storage Area, and an administrative and operations area. The SDA encompasses 97 acres, and waste is buried in approximately 35 of the 97 acres. Waste was disposed of in the landfill in unlined pits, trenches, soil vaults, and on Pad A (an above-grade disposal area). Historically, waste containing radioactive and hazardous substances was managed in accordance with laws and disposal practices current at that time. In 1970, burial of transuranic waste was prohibited. In 1984, disposal practices were modified to eliminate disposal of mixed waste (radioactive waste also regulated by the Resource Conservation and Recovery Act [RCRA; 42 USC $\S 6921$ et seq. 1984]). 
Since 1984, only contact and remote-handled LLW (i.e., radioactive only) has been disposed of in the SDA.

Disposal practices have evolved over time, including changes in disposal facility, waste treatment, and containers. Current disposal operations within the SDA are limited to subsurface burial of INL and tenant-generated contact and remote-handled LLW. Disposal of waste from offsite generators was discontinued in the early 1990s. Waste emplaced in the SDA is classified as either remote or contact-handled LLW, depending on radiation levels. In general, contact-handled LLW is stacked in an open pit and remote-handled LLW is entombed in concrete vaults in the southwestern corner of Pit 20. Large or bulky remote-handled LLW is buried in specially isolated areas within the open pit.

\section{A-2.1 Contact and Remote-Handled Low-Level Waste Pit Disposal}

SDA Pits 17 through 20 comprise the 5.6-acre excavated area currently used for disposal of contact and remote-handled LLW. Waste is stacked in the pits using forklifts and cranes. Stack height is limited by the self-supporting strength of containers and by administrative controls. As areas of the pits become full, waste is covered with fine-grained soil, compacted with dozers, and sloped for drainage. ATR ion-exchange resins are disposed of in the open pit. The resins are packaged in liners compatible with the $\mathrm{NuPac}^{\mathrm{TM}} 14-210 \mathrm{~L}$ cask, which is used for onsite transport of the resins to RWMC for disposal.

\section{A-2.2 Remote-Handled Low-Level Waste Concrete Vault Disposal}

Concrete vaults in the southwestern corner of Pit 20 are used for disposal of remote-handled LLW. Concrete vaults provide shielded disposal for remote-handled LLW from NRF and ATR. The vaults are constructed of precast, reinforced concrete sections resting on an integral base plate and are configured in honeycomb arrays. Each array is surrounded by soil for additional shielding and seismic stability. Void spaces between vaults in each array are filled with sand. Once full, each vault is covered with a reinforced concrete plug. Two hundred concrete vaults have been constructed in Pit 20.

Remote-handled LLW resins from NRF are packaged in liners and transported in a 55-ton scrap cask to the SDA for disposal in the concrete disposal vaults. Remote-handled LLW activated metals from NRF also are packaged in 55-ton cask liners and shipped in the same 55-ton scrap cask that is used for transporting NRF resins onsite. ATR ion-exchange resins are currently disposed of in the open pit, while ATR activated metals are in interim storage at the Reactor Technology Complex.

\section{A-3. CURRENT OFFSITE DISPOSAL OF CONTACT AND REMOTE-HANDLED LOW-LEVEL WASTE}

While the majority of INL-generated contact and remote-handled LLW is currently disposed of onsite at RWMC, certain contact-handled LLW streams are disposed of offsite because they do not meet RWMC's WAC. These waste streams include waste containing classified material and U.S. Department of Transportation (DOT) Class B and C waste, which is disposed of at NTS.

While Hanford was identified (in addition to NTS) as a regional disposal facility for disposal of DOE contact and remote-handled LLW, ongoing NEPA evaluation and anticipated litigation between DOE and the State of Washington over DOE's decisions under NEPA have eliminated disposal of INL contact- and remote-handled LLW at Hanford as a viable disposal alternative for current waste disposal activities. 
For shipment offsite, all waste must be packaged in DOT-compliant packaging. All INL-generated remote-handled waste is currently disposed of onsite or held in interim storage for decay or pending identification of a viable disposal pathway(s). Remote-handled LLW poses unique challenges in terms of packaging and shipping and acceptance by offsite disposal sites due to high radiation levels that require remote handling and adequate shielding for transportation and disposal.

The INL's NuPac ${ }^{\mathrm{TM}}$ 14-210L cask, which is used for transporting ATR ion-exchange resins onsite, is certified as a DOT Specification 7A package for low-specific activity resins. The cask fully satisfies DOT requirements as a Type A package; however, the $\mathrm{NuPac}{ }^{\mathrm{TM}}$ cask has not previously been received at an offsite disposal facility. The 55-ton scrap cask used for transporting NRF resins and activated metals onsite cannot be used for transport on public highways because it is not DOT certified. 